\title{
ENTREPRENEURIAL LEADERSHIP UNTUK MENYONGSONG REVOLUSI INDUSTRI 4.0
}

\section{Entrepreneurial Leadership: Outlook and Integration in Fourth Industrial Revolution}

\author{
Andreas Wijaya ${ }^{1)}$, Kevin Santoso ${ }^{2)}$ \\ 1)Manajemen/Fakultas IImu Sosial dan Humaniora, Universitas Bunda Mulia \\ 2)Manajemen/Fakultas IImu Sosial dan Humaniora, Universitas Bunda Mulia
}

Diterima 10 Juli 2020 / Disetujui 14 Agustus 2020

\begin{abstract}
The demand of labour scarcity problem had been surge while the availability of labour market outpacing the available job. The data from BPS (2020) shows people graduated from higher school had a largest contribution compared from the other. Looking at this situation Indonesia ministry of industry (Kemenperin) recall an action to give an outlook of Industrial Revolution as an opportunity to drive more entrepreneur in Indonesia. It believes, Indonesia have a prolific people to compete the other South East Asian Country. However, the novelty of COVID-19 pandemic hardly hit many sector business, some of business also furlough or even to rid off their employee. As a result, negative growth is unavoidable, in April- June accounted to decreased $-5,32 \%$ at least to be compared economic performance in year-to-year period. In order to cope the foresee situation, this community services had an initiative to emerged entrepreneurial leadership in industrial revolution era for higher education student. The aim of this services are to creating a young entrepreneur in future. Furthermore, two communication seminar was held in online media via (google meet) in Monday, mei $4^{\text {th }} 2020$ at $11.00 \mathrm{pm}$ until $13.00 \mathrm{pm}$. As a result, a positive feedback given by the student and they suggested to recall again with the specific issue in entrepreneurship area.
\end{abstract}

Keywords: Entrepreneurship, Leadership, Entrepreneurial Leadership, Revolution Industry, Labour

\begin{abstract}
ABSTRAK
Jumlah angkatan kerja yang semakin bertambah berbanding terbalik dengan partisipasi angkatan kerja justru mengalami tren yang berbeda terdapat selisih sebanyak $0,15 \%$ yang berarti jumlah pengangguran bertambah dibandingkan dengan angkatan yang bekerja. Berdasarkan data dari BPS (2020); secara mendalam TPT Sekolah Menengah Kejuruan (SMK) masih yang paling tinggi diantara tingkat Pendidikan lain, sebagai bentuk respon dari Kemenperin (2018) yang selalu mendorong masyarakat Indonesia untuk bergerak dalam bidang kewirausahaan terutama dari persiapan menyambut Revolusi Industri 4.0, agar siap berkompetensi dengan negara-negara lain, namun kondisi saat ini yang sedang dilanda pandemic COVID-19 membuat ekonomi Indonesia pada periode April - Juni 2020 terkontraksi $-5,32 \%$ di bandingkan periode yang sama tahun lalu (year-on-year/YOY. Untuk mengantisipasi menegakkan kepemimpinan wirausaha sebagai landasan membangun dan mengayomi para anggota dalam bisnisnya menjadi proaktif dalam mengolah peluang maupun resiko pada perubahan . Melalui kegiatan pengabdian ini, rangkaian acara dimulai pada hari senin, 4 mei 2020 pada PK 11.00-13.00 dengan metode daring via google meet yang dibagi menjadi dua sesi, dimulai dari gambaran tentang revolusi industri 4.0 dan penjelasan mengenai peran kewirausahaan untuk menghadapi revolusi industri. Hasil dari pengabdian ini mendapat tanggapan yang positif dari peserta dan para peserta pun antusias untuk diadakan kembali acara ini secara mendalam tentang tema kepemimpinan. Adapun harapan dari hasil pengabdian ini dapat menciptkan bibit para wirausahawan yang nantinya dapat memberikan kemajuan dalam pembangunan ekonomi negara
\end{abstract}

Kata Kunci: Kewirausahaan, Kepemimpinan, Revolus Industri, Kepemimpinan Kewirausahaan, Tenaga Kerja

Coresponding Author: awijaya@bundamulia.ac.id 


\section{PENDAHULUAN}

Sesi awal akan membahas tentang pengenalan dari seorang pemimpin yang kemudian membandingkan antara pedagang dan kewirausahaan untuk menjelaskan pandangan bagi para siswa. Dilanjutkan dengan penjelasan revolusi industri pertama sampai dengan revolusi industri 4.0 serta outlook mengenai dampak pandemik terhadap pertumbuhan ekonomi di Indonesia.

Sesi selanjutnya, para siswa diajak brainstorming tentang perananan vital dari seorang pemimpin. Membandingkan beberapa pemimpin menjadi tema yang menarik agar para siswa memahami definisi dari kepemimpinan kewirausahaan serta dapat membedakan antara berbagai bentuk gaya kepemimpinan.

Pada tahun 2020, Badan Pusat Statistik Indonesia mencatat sekitar 137,91 juta jumlah angkatan kerja di Indonesia, Namun tingkat partisipasi angkatan kerja justru mengalami tren yang berbeda, terdapat selisih sebanyak $0,15 \%$ yang berarti jumlah pengangguran bertambah dibandingkan dengan angkatan yang bekerja. Secara mendalam TPT Sekolah Menengah Kejuruan (SMK) masih yang paling tinggi diantara tingkat pendidikan lain, yaitu sebesar 18,49 $\%$ dibangingkan dengan beberapa kategori angkatan yang belum bekerja dengan persentase di bawah 10\%. Melihat hal tersebut merupakan suatu fenomena yang memerlukan kajian dari sumber daya manusia sejak dini, agar nantinya dapat menekan kembali angka pertumbuhan. Beberapa usaha dari pemerintah pun dilakukan, seperti yang sudah diungkapkan oleh Kemenperin (2018) yang selalu mendorong masyarakat Indonesia untuk bergerak dalam bidang kewirausahaan terutama dari persiapan menyambut Revolusi Industri 4.0, agar siap berkompetensi dengan negara-negara lain seperti Malaysia, Thailand dan Singapura. Sebelumnya pada tahun 2019, para akademisi maupun praktisi sudah mulai memperkirakan perkembanan revolusi industri 4.0 akan memberikan dampak yang cukup signifikan terutama di negara Asia Tenggara. Perikraan pertumbuhan yang diprediksi oleh e-Conomy SEA 2019 membawakan dampak positif bagi Indonesia

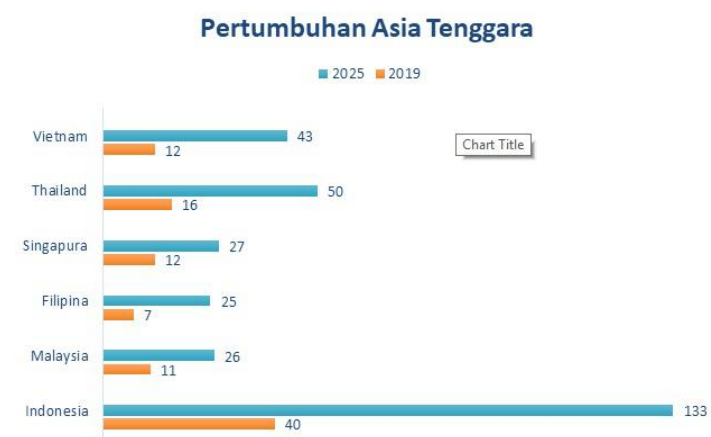

Gambar 1: Perikiraan pertumbuhan ekonomi Asia Tenggara pada tahun 2019-2025

Sumber : e-Conomy SEA 2019

Berdasarkan data tersebut dapat dilihat bahwa Indonesia memiliki peluang untuk tumbuh lebih tinggi dibandingkan dengan beberapa negara lainnya, hal ini didorong oleh perkembangan teknologi pada era revolusi 4.0 yang begitu membuat banyak perubahan. Dimulai dari kendaran daring sampai dengan website yang menawarkan toko online berbasis market place. Dengan peluang ini diharapkan dapat membangun potensi kewirausahaan yang bekerjasama dengan teknologi. Hal ini dapat dilihat dari hasil penelitian Rocko (2017) menjalankan bisnis yang sukses pada era transisi menuju Revolusi Industri 4.0, membutuhkan dasar dari entrepreneurial leadership (kepemimpinan kewirausahaan) sebagai landasan membangun dan mengayomi para anggota dalam bisnisnya menjadi proaktif dalam mengolah peluang maupun resiko pada perubahan.

Namun tantangan yang terjadi saat ini adalah pandemik virus korona yang melanda hampir di seluruh negara, membuat beberapa negara 
menerapkan sistem lockdown yang juga di terapkan di Indonesia. Hal ini menjadikan ekonomi Indonesia pada periode April - Juni 2020 terkontraksi $-5,32 \%$ di bandingkan periode yang sama tahun lalu (year-onyear/YOY). Lebih lanjut pada hal ini menjadikan catatan bahwa ekonomi saat ini berada dalam tanda tanya besar, dan mungkin dapat mengalami penurunan. Melihat potensi perubahan model bisnis persaingan serta pandemik yang akan terjadi, maka Pengabdian Kepada Masyarakat ini bermaksud memberikan pelatihan mengenai Entrpeneurial sejak dini kepada para siswasiswa sebagai bekal untuk menyongsong Revolusi Industri 4.0

\section{IDENTIFIKASI MASALAH}

- Jumlah angkatan kerja yang semakin bertambah berbanding terbalik dengan partisipasi angkatan kerja justru mengalami tren yang berbeda,

- Secara mendalam TPT Sekolah Menengah Kejuruan (SMK) masih yang paling tinggi diantara tingkat pendidikan lain.

- Kemenperin (2018) yang selalu mendorong masyarakat Indonesia untuk bergerak dalam bidang kewirausahaan terutama dari persiapan menyambut Revolusi Industri 4.0, agar siap berkompetensi dengan negara-negara lain.

- Indonesia memiliki peluang untuk tumbuh lebih tinggi dibandingkan dengan beberapa negara lainnya, hal ini didorong oleh perkembangan teknologi pada.

- Ekonomi Indonesia pada periode April - Juni 2020 terkontraksi -5,32\% di bandingkan periode yang sama tahun lalu (year-on-year/YOY)

\section{TINJAUAN PUSTAKA}

Kewirausahaan memiliki arti keberanian dan 'usaha' sendiri memiliki arti kegiatan bisnis yang bersifat komersial maupun nonkomersial. Sehingga kewirausahaan dapat pula diartikan sebagai keberanian seseorang untuk melakukan / melaksanakan suatu kegiatan bisnis. Dalam Bahasa Inggris, wirausaha dikenal dengan sebutan 'entrepreneur. Berdasarkan pemahaman dari Fahmi (2013), kewirausahaan merupakan ilmu dari pengembangan dan pembangunan yang mencakup kreativitas dan resiko dalam menghasilkan karya. Sehingga dapat disimpulkan bahwa wirausahawan adalah orang yang menciptakan bisnis baru dengan mengambil risiko dan ketidakpastian demi mencapai keuntungan dan pertumbuhan dengan cara mengidentifikasi peluang dan menggabungkan sumber daya yang diperlukan untuk mendirikannya. Peran dari seorang wirausaha menurut Suryana (2009) d menjelaskan kosep kewirausahaan merujuk pada sifat, watak, dan ciri-ciri yang melekat pada seseorang yang mempunyai kemauan keras untuk mewujudkan gagasan inovatif ke dalam dunia usaha yang nyata dan dapat mengembangkannya dengan tangguh. Berbagai fungsi dan peran wirausaha menurut Suryana (2009) antara lain :

- Mikro: penemu dan perencana yang menciptakan produk/jasa terbaru yang meliputi teknologi, proses, ide, organisasi. Dan perencana wirausaha memberikan susunan strategi usaha baru, perencanaan ide dan peluang meraih sukses

- Makro: peran wirausaha menciptakan lapangan kerja dan suatu penopang dalam perekonomian suatu negara

Keuntungan menjadi wirausaha antara lain:

- Membuka peluang mencapai tujuan yang dikehendaki oleh pribadi

- Membuka peluang dalam mendemonstrasikan kemampuan dan potensi 
- Membantu masyarakat dengan usaha konkrit

Kerugian berwirausaha antara lain:

- Memperoleh pendapatan tidak pasti

- Bekerja keras dan memiliki jam waktu yang panjang

- Tanggung jawab yang besar dalam setiap keputusan yang di ambil

Beberapa hasil survey yang dilakukan suryana (2009) terdapat berbagai faktor yang dapat menyebabkan wirausaha gagal dalam menjalankan usaha baru nya:

- Tidak memiliki kompetensi dalam manajerial

- Kurangnya pengalaman yang dimiliki

- Tidak memiliki manajemen yang baik dalam mengelola keuangan

- Kurangnya pengawasan

- Tidak konsisten

Menurut runtutan waktunya, terdapat 3 teori kewirausahaan, yaitu :

1. Teori Neo Klasik. Teori ini memandang perusahaan sebagai istilah teknologis, dimana manajemen hanya mengetahui biaya dan penerimaan perusahaan dan sekedar melakukan kalkulasi matematis untuk menentukan nilai optimal dari

2. Teori Non Klasik ini tidak cukup mampu menjelaskan isu-isu mengenai kewirausahaan sebab kemandirian sangat tidak terlihat dalam teori tersebut. Karena memang pada masa lampau belum adanya urgensi mengenai masalah kemandirian.

3. Teori Perilaku. Di teori ini, lebih menyoroti bagaimana seorang wirausahawan harus memiliki kecakapan dalam mengorganisasikan usaha, mengatur keuangan serta halhal terkait, membangun relasi / jaringan, dan memasarkan produk. Atau dengan kata lain, dalam teori tersebut dibutuhkan pribadi yang supel dan pandai bergaul untuk dapat memajukan suatu usaha.
Berdasarkan teori kewirausahaan tersebut mengindikasikan bahwa mengatur keuangan dalam pengorganisasian perusahaan membutuhkan suatu keahlian dari pribadi yang menjiwai seperti kepemimpinan kewirausahaan. Menurut Kuratko \& Hodgetts (2007) kepemimpinan kewirausahaan adalah suatu proses dinamis dari visi, perubahan, dan penciptaan. Hal ini membutuhkan sebuah aplikasi energi dan gairah terhadap penciptaan dan implementasi ide-ide baru dan solusi kreatif. Faktor - faktor yang membentuk seorang wirausaha adalah kemauan untuk mengambil risiko dalam hal waktu, ekuitas, atau karir; kemampuan untuk merumuskan sebuah tim yang efektif; keterampilan kreatif untuk mengumpulkan sumber daya yang dibutuhkan; keterampilan dasar membangun rencana bisnis yang kuat; dan mampu mengenali resiko ancaman menjadi peluang. Selain itu menurut Yusuf Esmer dan Faruk (2017) kepemimpinan kewirausahaan adalah : Kepemimpinan yang melibatkan strategi dalam organisasian dan memotivasi sekelompok orang untuk mencapai tujuan bersama melalui: inovasi, optimalisasi risiko, mengambil keuntungan dari peluang, mengelola lingkungan organisasi yang dinamis.

Ada banyak ahli manajemen yang merumuskan definisi-definisi tentang Kepemimpinan atau Leadership. Salah satu diantaranya adalah definisi kepemimpinan menurut Gareth Jones and Jennifer George, (2012). Menurutnya, kepemimpinan adalah proses dimana seorang individu mempunyai pengaruh terhadap orang lain dan mengilhami, memberi semangat, memotivasi dan mengarahkan kegiatan-kegiatan mereka guna membantu tercapai tujuan kelompok atau organisasi. Menurut (Stephen P. Robbins, 2016), kepemimpinan adalah kemampuan untuk mempengaruhi suatu kelompok ke arah tercapainya tujuan. Sedangkan definisi kepemimpinan menurut (Richard L. Daft, 2011) adalah kemampuan mempengaruhi orang yang mengarah kepada pencapaian tujuan. Dari beberapa definisi tersebut, sangat jelas dikatakan bahwa kepemimpinan adalah fungsi manajemen yang erat keterkaitannya dengan pencapaian tujuan organisasi. Orang yang melakukan fungsi kepemimpinan ini 
biasanya disebut dengan "pemimpin" atau dalam bahasa Inggris disebut dengan "Leader". Berdasarkan definisi dari (Ricky W. Griffin, 2014), pemimpin adalah individu yang mampun mempengaruhi perilaku orang lain tanpa harus mengandalkan kekerasan; pemimpin adalah individu yang diterima oleh orang laim sebagai pemimpin.

Lebih lanjut, bedasarkan hasil riset dari Blake (1964) dan Moulton dalam manajerial grid terdapat 5 hal yang perlu diperhatikan oleh pemimpin dalam mengelola organisasinya, antara lain: Country club style, Team style, Middle of the road style, Improvished style, product or perish style seperti yang tergambar pada bagan di bawah ini :

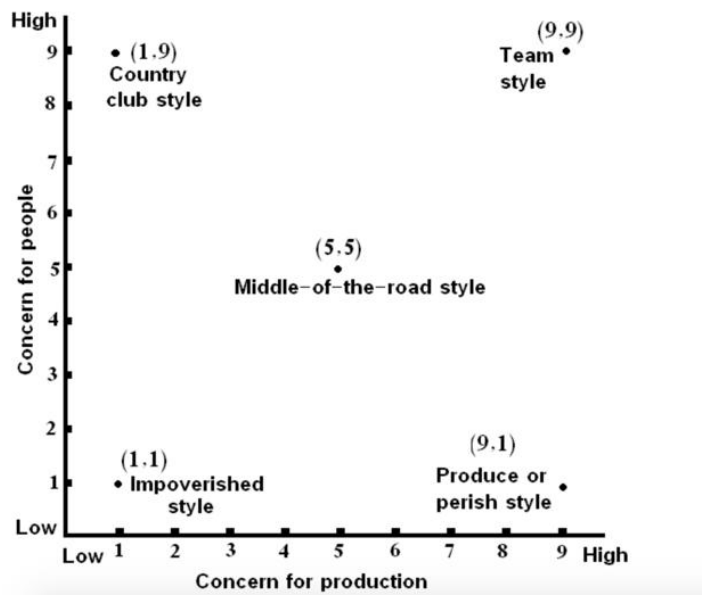

Gambar 2. Managerial Grid

Sumber : Blake dan Moulton (1946)

Pada penelitian mengenai teori gaya kepemimpinan yang dilakukan oleh Blake dan Moulton dengan membuat bagan yang pada sumbu $X$ adalah fokus terhadap produk dan pada sumbu $\mathrm{Y}$ adalah fokus terhadap karyawan. Dan dari penelitian ini dapat disimpulkan bahwa terdapat lima gaya kepemimpinan yang seringkali dilakukan oleh pemimpin. Dibawah ini akan dijelaskan teoriteori gaya kepemimpinan

1. Country club style :

Kepemimpinan yang akomodatif mengawasi bagaimana perasaan anggota tim. Pemimpin mengasumsikan bahwa selama karyawan bahagia dan merasa dibutuhkan, mereka akan bekerja keras dan berkinerja lebih baik.

2. Team syle memiliki pemimpin yang mampu menunjukkan semangat dalam pekerjaan mereka. Pemimpin mengelola produksi dan kebutuhan karyawan sehingga anggota tim memahami tujuan perusahaan. Dengan melibatkan banyak orang dalam menentukan kebutuhan produksi, mereka merasa berkomitmen dan ingin memiliki andil dalam menentukan seberapa sukses perusahaan tersebut.

3. Middle of the road style

kepemimpinan yang mencoba menjaga keseimbangan antara hasil dan kesejahteraan anggota.

4. Improvished style

Pemimpin yang memiliki gaya kepemimpinan demikian ini hanya memiliki sedikit atau bahkan tidak ada minat untuk menciptakan lingkungan kerja yang sehat, produktif dan dapat menyelesaikan dengan baik. Dengan sedikit minat dalam memotivasi atau memuaskan tim, hasilnya hampir selalu tidak terorganisir, kurang kesepakatan dan tidak adanya kepuasan

5. Product of perish style pemimpin seperti ini bersifat otoriter. Karena pemimpin seperti ini memiliki gaya kepemimpinan yang memiliki aturan, kebijakan, dan prosedur yang ketat. Dengan menganggap hukuman sebagai cara yang efektif untuk membuat anggota tim dan perusahaan menjadi lebih disiplin dalam bekerja, pendekatan ini dapat menghasilkan hasil produksi yang tinggi 
Selain gaya kepemimpinan yang disebutkan terdapat beberapa gaya kepemimpinan, seperti :

1) Kepemimpinan Otokratis. Gaya kepemimpinan ini melahirkan pemimpin yang sangat dominan dalam setiap pengambilan keputusan ataupun kebijakan. Dengan kata lain, kepemimpinan otokratis memusatkan kekuasaan pada dirinya sendiri dan cenderung membatasi inisiatif serta daya pikir dari para anggotanya.

2) Kepemimpinan Birokrasi. Gaya kepemimpinan ini biasa diterapkan dalam sebuah perusahaan dan akan efektif jika setiap karyawan mengikuti setiap alur prosedur dan melakukan tanggung jawab rutin setiap hari.

3) Kepemimpinan Partisipatif. Dalam kepemimpinan ini, pemimpin memberikan ruang gerak bagi para bawahan untuk dapat berpartisipasi dalam pembuatan suatu keputusan serta adanya suasana persahabatan dan hubungan saling percaya antar pimpinan dan anggota.

4) Kepemimpinan Delegatif. Sering disebut Laissez-faire, yang dimana pemimpin memberikan kebebasan secara mutlak kepada para anggotanya untuk melakukan tujuan dan cara mereka masing-masing.

5) Kepemimpinan Transaksional. Gaya kepemimpinan ini cenderung terdapat aksi transaksi antara pemimpin dan bawahan, dimana pemimpin akan memberikan reward ketika bawahan berhasil melaksanakan tugas yang telah diselesaikan sesuai kesepakatan.
6) Kepemimpinan Transformasional dalam kepemimpinan ini, pemimpin cenderung memiliki semangat yang positif untuk para bawahannya, yang dimana semangat positif tersebut ditunjukkan dengan tindakan kepedulian terhadap kesejahteraan dan kemajuan para bawahannya.

7) Kemampuan Melayani. Dalam kepemimpinan ini, pemimpin lebih mengutamakan kebutuhan, kepentingan, dan aspirasi dari para anggotanya daripada kepentingan pribadinya.

8) Kepemimpinan Karismatik. Dalam kepemimpinan ini, pemimpin memiliki pengaruh yang kuat atas para pengikut karena karisma dan kepercayaan diri yang ditampilkannya. Hal tersebut akan membuat para pengikutnya merasa kagum dan secara emosional percaya dan ingin berkontribusi bersama dengan pemimpinnya.

9) Kepemimpinan Situasional. Pemimpin dalam gaya ini lebih sering menyesuaikan setiap gaya kepemimpinan yang ada dengan tahap perkembangan para anggota yakni sejauh mana kesiapan dari para anggota melaksanakan setiap tugas.

\section{METODE PENELITIAN}

Kegiatan pengabdian
masyarakat ini menggunakan metode
komunikasi dua arah vertikal hal ini
dilakukan dengan maksud memberikan
informasi tepat guna bagi para peserta, yang
pada kali ini adalah para siswa/i.

Manfaat dari kelebihan dari komunikasi dua arah adalah sebagai berikut: 
- Adanya dialog antara komunikator dengan komunikan, sehingga menimbulkan kepuasan diantara kedua belah pihak,

- Informasi yang diterima menjadi lebih jelas, lebih akurat dan lebih tepat, karena dapat diperoleh langsung penjelasanya.

- Menghindari kesalah pahaman Komunikator dan komunikan bebas mengeluarkan pendapat masing-masing.

- Meyalurkan ide-ide komunikan dari berbagai sudut pemikiran yang berbeda

Rangkaian acara kegiatan ini dimulai pada hari senin, 4 mei 2020 pada PK 11.00-13.00 dengan metode daring via google meet, Sesi awal akan membahas tentang pengenalan dari seorang pemimpin yang kemudian membandingkan antara pedagang dan kewirausahaan untuk menjelaskan pandangan bagi para siswa. Dilanjutkan dengan penjelasam revolusi industri pertama sampai dengan revolusi industri 4.0 serta outlook mengenai dampak pandemik terhadap pertumbuhan ekonomi di Indonesia.

Sesi selanjutnya, para siswa diajak brainstorming tentang perananan vital dari seorang pemimpin. Membandingan beberapa pemimpin menjadi tema yang menarik agar para siswa memahami definisi dari kepemimpinan kewirausahaan serta dapat membedakan antara berbagai bentuk gaya kepemimpinan.

\section{HASIL DAN PEMBAHASAN}

Selama pengabdian ini dijelaskan bahwa tantangan dalam menghadapi era revolusi industri 4.0 membuat gebrakan hampir di semua sektor bisnis di Indonesia. Beberapa diantaranya mampu berkembang dan melaju seperti pada pertumbuhan bisnis yang berbasis teknologi memberikan dampak yang cukup positif, sedangkan beberapa area membutuhkan penyesuaian menghadapi tantangan tersebut. Berdasarkan teori dari Özüdoğru et.al (2018) pemimpin kewirausahaan banyak dipakai oleh beberapa pengusaha dalam menjalankan bisnisnya.

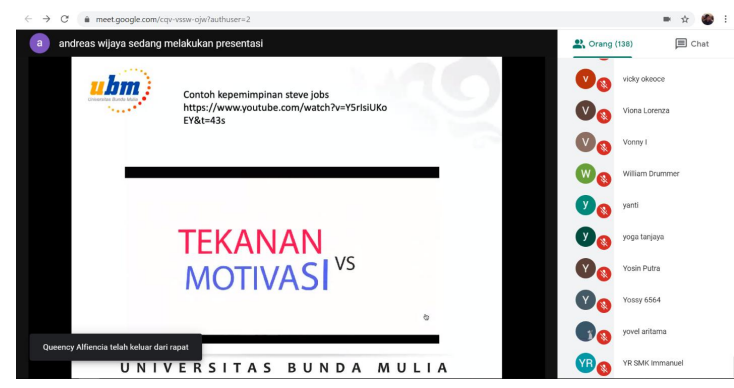

Gambar 3. Poin Kepemimpinan

Sumber : Penulis (2020)

Memberikan arahan bagi para pekerjanya dan mampu melihat sebuah ancaman menjadi peluang adalah kunci menghadapi perubahan.

Hasil dari kegiatan pengabdian kepada masyarakat yang diberikan dari hasil umpan balik siswa/i SMK Immanuel antara lain: Para siswa siswa merasa manfaat pada kegiatan ini sudah baik, relevansi pada kegiatan ini sudah baik, materi pada kegiatan ini sudah baik, ketepatan media/ sarana pada kegiatan ini sudah baik, penambahan pengetahuan yang diberikan mengenai "Entrepreneurial Leadership untuk Menyongsong Revolusi Industri 4.0"pada kegiatan ini sudah baik. "Proses atau kegiatan pelaksanaan" menunjukkan bahwa peserta siswa/i SMK Immanuel Pontianak merasa seluruh proses kegiatan pada acara ini sudah berjalan dengan baik. Dari segi pemberian materi "Penambahan pengetahuan/keterampilan yang dapat diaplikasikan peserta" menunjukkan bahwa peserta siswa/i SMK Immanuel Pontianak merasa dengan adanya kegiatan ini pengetahuan peserta semakin bertambah khususnya mengenai "Entrepreneurial Leadership untuk Menyongsong Revolusi Industri 4.0" 
Hasil evaluasi bagi pembicara pun mendapatkan tanggapan yang baik dari siswasiswa SMK Immanuel, dari hasil "Kemampuan atau penguasaan terhadap materi oleh narasumber sudah baik, penyampaian materi oleh narasumber sudah baik, kemampuan menggunakan metode oleh narasumber sudah baik, kemampuan menjawa pertanyaan oleh narasumber sudah baik merasa penguasaan materi oleh narasumber sudah baik, sehingga penciptaan suasana yang mendukung semakin membuat para siswa/i merasa nyaman selama penyampaian materi ini

\section{SIMPULAN}

Dengan adanya kegiatan pengabdian kepada masyarakat ini, diharapkan dapat memberikan sebuah pandangan yang menarik bagi para siswa/i dalam menumbuhkan minat menjadi wirausaha. Dengan bertumbuhnya wirausaha akan menjadikan dampak yang positif bagi pertumbuhan ekonomi, terutama dalam membangun lapangan pekerjaan dan memberikan hasil laju pertumbuhan. Dari hasil pengabdian ini pun memberikan tanda bahwa semangat berwirausaha sejak dini cukup tinggi bagi mahasiswa, sehingga untuk kedepannya diharapkan dapat melanjutkan kembali hasil dari pengabdian ini dengan tambahan dari sisi teknologi yang dimana saat ini hampir seluruh sector menggunakan bantuan dari teknologi dalam menyongsong revolusi Industri 4.0

\section{DAFTAR PUSTAKA}

Fahmi, Irham (2013). Kewirausahaan. Teori, kasus, dan solusi. Bandung: Alfabeta

George, Jennifer and Gareth R Jones. (2012). Understanding and Managing Organizational Behavior. Pearson Education, Inc, New Jersey.

Griffin, Ricky W., and Moorhead, Gregory., 2014. Organizational Behavior: Managing People and Organizations.

Eleventh Edition. USA: South Western.
Hodgetts, Richard M. And Kuratko, Donald F. (2007). Small Business Management. John Wiley \& Sons Inc

Özüdoğru, A. Göksu \& Ergün, Esra \& Ammari, Djihane \& Students, \& Görener, Ali. (2018). How Industry 4.0 Changes Business : A Commercial Perspective. 4. 84-95.

Rocko Andrea (2017). Industry 4.0 Concept: background and Overview. IJIM. Vol 11, No5, 2017

Suryana (2015) Kewirausahaan : Kiat dan Proses Menuju Sukses. Suryana. Salemba Empat 4, 298, 2015

Richard L. Daft, (2011). Era Baru Manajemen. Jakarta. Salemba Empat

Robbins, Stephen P. and Mary Coulter. 2016. Manajemen, Jilid 1 Edisi 13, Alih. Bahasa: Bob Sabran Dan Devri Bardani P, Erlangga, Jakarta

Robert R. Blake and Jane S. Mouton. The Managerial Grid. Houston Texas: Gulf Publishing Co., 1964.

Yusuf Esmer dan Faruk (dan (2017). Entrepreneurial Leadership : A Theoritical Framework"

WEBSITE :

https://kemenperin.go.id/artikel/19926/Indone sia-Butuh-4-Juta-Wirausaha-Baru-untukMenjadi-

https://www.bps.go.id/publication/2020/06/26 /7b90d91146f0fd8dee4369df/indikator-pasartenaga-kerja-indonesia-februari-2020.html

https://www.bain.com/insights/e-conomysea-2019/ 